\title{
Kierkegaard's Concept of History
}

\author{
GEORGIOS PATIOS \\ Department of Philosophy and History of Science, National and Kapodistrian University of Athens, \\ Panepistimiopolis, 15784 Ilissia, Athens, Greece \\ gpatios@phs.uoa.gr
}

ORIGINAL SCIENTIFIC ARTICLE / RECEIVED: 04-01-14 ACCEPTED: 09-04-14

ABSTRACT: The purpose of this paper is twofold: first, to provide an overview of the Kierkegaardian approach to history; second, to define in more details some of the main characteristics of his concept of history. Throughout the paper, my overall aim will be to demonstrate that Kierkegaard, although he never provides a complete theory or philosophy of history, nevertheless presents us with a concept of the nature of history. I refer to a 'concept' because I consider his thinking about history to constitute a coherent intellectual effort to describe and understand the nature of the historical. A concept is not a full-blown theory, but nor is it a mere rhapsody.

KEYWORDS: Faith, freedom of will and choice, Kierkegaard, philosophy of history.

\section{Introduction}

Kierkegaard wrote three texts under the same pseudonym, Johannes Climacus: Johannes Climacus, (1841-2, hereafter JC), Philosophical Fragments (1844, hereafter PF) and Concluding Unscientific Postscript to Philosophical Fragments (1846, hereafter CUP) (Kierkegaard 1987). Without attempting to argue that the existence of a shared pseudonym is sufficient evidence for considering these texts to be proposing the same philosophical theory, I will claim that Kierkegaard's understanding of 'actuality', 'possibility', 'necessity', 'knowledge of history', 'doubt', 'belief', and 'passion' remains constant through-out these three books. Thus, my argument presupposes the conceptual unity of these texts.

In $P F$, Kierkegaard's primary interest is the problem of the Incarnation. On the face of it, therefore, the work may seem theological. My point of departure, however, is that through his struggle to theorise the Incarnation, Kierkegaard passes by way of history. Hence, in order to discuss the Incarnation, Kierkegaard ends up exploring the very nature of history. 


\section{The Aim of this Paper}

In this paper, I will contend that: a) for Kierkegaard history is always the history of human beings; hence its nature is directly related to their freedom of will. In other words, human beings make history by using this freedom; and b) Kierkegaard considers historical fact as an uncertain object of cognition. To put it bluntly, we cannot achieve the same scientific accuracy in our knowledge of history as we do in the natural sciences.

Therefore, in what follows I focus on the answers that Kierkegaard gives: a) to the ontological question 'What is the nature of history?' and b) to the epistemological question 'Which is the nature of our historical knowledge?'. I will argue that these questions cannot be separated from each other, according to Kierkegaard: ontology and epistemology are intertwined. In fact, $\mathrm{Ki}-$ erkegaard argues that for his epistemological thesis that historical knowledge cannot be of the same precision as knowledge of the laws of nature, precisely because of an ontological thesis that there is no necessity in history, hence no general and necessary laws. ${ }^{1}$

In order to demonstrate the above interconnections between the ontological and the epistemological in Kierkegaard's concept of history, I pursue an extended and detailed analysis of 'The Interlude' in PF. I do so because, in many ways the Interlude provides the very core of Kierkegaard's concept of history.

\section{The Interlude}

Robert C. Roberts takes 'the Interlude' to be 'a defense of a thesis concerning historical beliefs in general' (1986: 99). Jacob Howland argues that '[C]limacus's general aim is clear: he wants to safeguard faith from the tyranny of philosophical reason... [H]e hopes to refute the doctrine that history is the unfolding of necessity...' (2006: 158). Peter Fenves claims that Climacus here argues against any kind of secure historical knowledge because 'such a [temporal] moment discloses only the constant annihilation of possibility in actuality...' (1993: 132).

What all these commentators share, despite all their ultimately divergent interpretations, is the contention that 'the Interlude' contains Kierkegaard's concept of history in nuce.

However, this is where agreement ends, for each of these commentators diverge considerably both in what they understand Kierkegaard's concept of

\footnotetext{
${ }^{1}$ Kierkegaard's 'necessity' is logical necessity and not causal necessity. For Kierkegaard however, the lack of logical necessity within history renders problematic any application of necessary historical laws that could help us make a historical 'prognosis'.
} 
history to be and in their evaluation of how cogent Kierkegaard's argument is. Hence, Roberts and Fenves argue that Kierkegaard in 'the Interlude' tries to answer the epistemological question of the nature of the historical knowledge. For example, Roberts holds that: '[T]he Interlude is organized as a refutation of two theses: First, that the truths of history are necessary truths; and second that they are knowable by the direct deliverances of the senses' (1986: 101). Similarly, Peter Fenves understands 'the Interlude' as an argument against historical knowledge and he argues that for Climacus:

...[I]t no longer makes sense to assert that one can recognise a temporal moment and thus gain historical knowledge...So faith is a form of knowledge; it both provides a criterion for unification and refuses the principal criterion of all thought. (1993: 132)

On the other hand, Mercer focuses on the ontological questions the Interlude raises. He argues that the 'Interlude' is 'related to the structures of the self and its relation to time... The problem of necessity is discussed, but in relation to the problem that necessity creates for human freedom, history, and existence' (2000: 119).

Finally, there are a number of scholars who treat the Interlude merely as a polemic against Hegel. It is here, they argue, Kierkegaard reveals himself in direct opposition to Hegel (or to Martensen). For example Niels Thulstrup argues that within the Interlude Kierkegaard is able to demonstrate the differences between his own 'conceptual clarification of history' and Hegel's philosophy of history. The main difference here, moreover, concerns the role that necessity plays in history. Hegel finds necessity within history while Kierkegaard is excluding necessity from history (1980: 362-364).

Jon Stewart similarly conceives the Interlude in terms of Kierkegaard's relationship with Hegelian thinkers. He argues that 'Climacus uses the argument about the categories of possibility, actuality, and necessity as the preliminary analysis for his account of history, which now follows in "the Interlude" (2003: 359). And what is crucial is that this account of history was a polemic aimed at Martensen, specifically his "Lectures on the History of Modern Philosophy from Kant to Hegel" delivered in the Winter Semester $1838-1839 .^{2}$

In what follows, I argue that all the above interpretations are incomplete. Rather, in the Interlude Kierkegaard attempts to answer both the ontological and the epistemological question simultaneously. Indeed, furthermore, even if Kierkegaard did intend to polemicise against a specific philosopher, in so doing he generates his own authentic concept of history; hence, what is at

${ }^{2}$ Stewart (2003: 374). Both Thulstrup and Stewart consider the 'Interlude' as revelatory of Kierkegaard's thinking on history. 
stake in the Interlude is not the question of whom it is directed against but rather the question of what Kierkegaard's arguments are.

Kierkegaard himself underlines the importance of the 'Interlude':

If a speculative thinker were to say that he comprehended the necessity of a historical phenomenon, I would indeed bid him to occupy himself for a moment with the misgivings set forth in all simplicity in the Interlude between chapters IV and V of Fragments. (1992: Vol. I, 53-54)

While the question about who Kierkegaard considers to be a 'speculative thinker' is one which continually rages in the critical literature, for my purposes the crucial point is that Kierkegaard intends the Interlude as an argument about the nature of a historical phenomenon.

$P F$ itself begins with these three questions regarding the nature of 'history'. And yet Climacus says nothing about history in the first few chapters of the book. It is only when the reader reaches the Interlude that one finds Climacus discussing issues closely related to historical phenomena.

What becomes apparent to the reader at this point is the focus of the Interlude on temporality (past and future) and the relation of necessity to this temporality (along with the latter's relation to the other modalities). History concerns the past and any historical fact is by its nature something that is temporal. Hence, it becomes even clearer that the Interlude is essentially concerned with history, when one reads its subtitles:

a) 'Coming into existence'

b) 'The historical'

c) 'The past'

I will examine each of these in turn in what follows.

\section{Coming into existence}

Before we proceed to an analysis of Climacus' arguments, we must clarify one central issue, namely the meaning of 'existence'. The Hongs write that ' $E x-$ istence," "exist," pertain to temporal and spatial being or actuality' $(P F, 297)$. Climacus explains his own view of the meaning of 'existence' in the third chapter of PF, 'The Absolute Paradox'. Here, Climacus defines 'existence' in a long note, arguing against Spinoza's theory of 'existence':

Consequently, [for Spinoza], the more perfect, the more being; the more being, the more perfect. This, however, is a tautology...Consequently, the more perfect the thing is, the more it is; but its perfection is that it has more esse in itself, which means that the more it is, the more it is...He [Spinoza] explains perfectio by realitas, esse [he explains perfection by reality, being]... But to go on, what is lacking here is a distinction between factual being and ideal being... $(P F, 41)$ 
This argument is well-known as a proof of God's existence: God is the most perfect being; the most perfect being incorporates existence; therefore God exists. Yet, in opposition to this, Climacus identifies a radical difference between 'factual being' and 'ideal being'. Climacus dissociates essence from existence. Hence, Climacus separates the ideas we have of objects (any kind of object, even God) and the actuality of the existence of these objects. Theologically, what is at issue here is the possibility of a logical explanation of the Incarnation, and it is for this reason he concludes this note: '.... for the difficulty is to grasp factual being and bring God's ideality into factual being' (PF, 42).

It seems that Climacus considers existence to be completely different from ideality. Ronald M. Green argues that Climacus here relies heavily on Kant's arguments against the ontological proof of the existence of God (1992: 122-123). The most important issue here, however, is Climacus' account of existence. Existence is not simply an attribute of essence. Existence is 'factual being'. The simplest way to understand 'existence' is to relate it to spatiotemporal 'facts'. 'Factual being' is not an essence but a given fact within the spatio-temporal conditions of our universe. ${ }^{3}$

With this conceptual clarification in mind, the first question that Climacus asks in the Interlude runs:

How is that changed which comes into existence [blive til], or what is the change

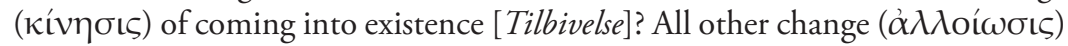
presupposes the existence of that in which change is taking place, even though the change is that of ceasing to be in existence [at voere til]. $(P F, 73)$

Every change that occurs in an entity that exists, presupposes that something in that entity remains the same, ensuring an identity before, at the time of and after the occurrence of change. If the change is a change in space

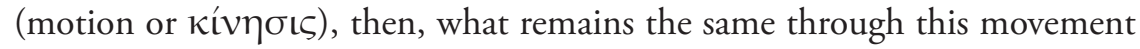
is the entity's body. If the change is a change in the body of an existing thing ( $\alpha \lambda \lambda$ oí $\omega \sigma \iota \varsigma)$, then what remains the same through this change is the identity of the thing. When people get older, their body changes but their identity remains the same.

When something comes into existence, what exactly is the change that occurs to that thing? In other words, when something comes into our world, can we talk of a change, and if yes, what exactly is that change? Kierkegaard is

\footnotetext{
${ }^{3}$ Kierkegaard's 'factuality' of existence refers specifically to its actualization within space and time. Historical occurrence is always something that occurs as an actuality. Kierkegaard's 'factuality' is identical to this 'actuality'. The Kierkegaardian 'given fact' refers only to its complete actualization within temporality and bears no relation to the possibility of being cognized.
} 
here tapping into a whole philosophical tradition which struggles to theorise such change adequately. This is because in order for a thing to change while entering our world, something must remain the same and so ensure an identity before, during and after the entrance of that thing into existence. ${ }^{4}$

If, in coming into existence, a plan is intrinsically changed, then it is not this plan that comes into existence; but if it comes into existence unchanged, what, then, is the change of coming into existence? $(P F, 73)$

Climacus argues that the only change we can identify in a thing that comes into existence 'is not in [its] essence but in [its] being' and more specifically 'from not existing to existing' ( $P F, 73)$. In this way when something new comes into existence, what really happens is a change in its being; before the change its being was 'not-being' and after the change it consisted in a 'positive' being. Having said that, Climacus argues, can we talk of the same thing before and after its coming into existence? In response, he argues that only in the case of possibility and its actualisation can we legitimately speak of the same thing passing through the change of 'coming into existence'. To understand this, however, we must proceed further with his argument.

Climacus's next step is to identify 'not-being' with possibility and 'being' with actuality:

But such a being that nevertheless is a non-being is possibility, and a being that is being is indeed actual being or actuality, and the change of coming into existence is the transition from possibility to actuality. $(P F, 74)$

On the basis of such identification Climacus goes on to pinpoint the essential difference between ideal being and factual being. Only the latter exists in our spatio-temporal world and participates in actuality. Immediately, one must consider a possible objection to Climacus' thesis: the only thing that seems to remain the same when a possibility is actualised is its essence or its ideality. For what underlies the transition from non-being to existence, is the very 'idea' of that being. Climacus however, has already refuted the existence of the 'ideal'. Furthermore, he now reinforces this refutation by stating that: '[T] he necessary is always related to itself and is related to itself in the same way, [thus] it cannot be changed at all' $(P F, 74)$. His argument is clear: if the necessary cannot change at all, then the necessary cannot come into existence, because every coming into existence is a change.

In consequence, the following picture emerges: Climacus ascribes necessity to the ideal and distinguishes both of them from 'existence'. What remains to be understood, however, is the absolute opposition that Climacus goes on to infer between existence and necessity, ideal and historical occurrence.

\footnotetext{
${ }^{4}$ Kierkegaard's analysis here is essentially Aristotelian. See Gonzalez (2007: 313).
} 
Mercer interprets Kierkegaard's absolute opposition between necessity and existence, as a logical conclusion. He argues that if the necessary is an actuality, then the necessary must first becomes possible. If however, the necessary is possible, then 'one could conclude that the necessary is also not possible' (2000: 122). Hence, necessity is not an actuality.

I argue that to interpret Kierkegaard's absolute dissociation of necessity and actuality in this way may provide the basis of his argument, but ultimately it does not fully capture Kierkegaard's point regarding history and necessity. Kierkegaard is providing more than a logical analysis. As we shall see, Kierkegaard argues that doubt is not a matter of a possible lack of knowledge but a matter of will. In this way, Kierkegaard argues that we cannot aspire to overcome doubt with the acquisition of more knowledge. To overcome doubt is not a matter of knowing 'historical' necessities. To overcome doubt is purely a matter of (free) will. Kierkegaard thus does not remain at the level of a purely logical analysis of the paradox of a possible necessity. Rather, his argument aims to make apparent the need (regarding historical existence) for a shift from epistemology to moral decisions. If we want to rule out doubt from history we do not need knowledge but will. We fail to fully understand this if we believe that Kierkegaard wants to make a logical analysis.

\section{Necessity/Freedom}

In order, for us, to fully capture the way Kierkegaard understands the nature and the role of freedom in history we must closely examine and analyse his overall argument about necessity and freedom in history (coming into existence).

Climacus' next step in the Interlude is to claim that if necessity cannot be a part of any 'coming into existence', then 'All coming into existence occurs in freedom...Every cause ends in a freely acting cause' $(P F, 75)$. At stake in this claim are the following presuppositions:

a) Necessity and existence are incompatible spheres.

b) Everything that comes into existence, (thus into actuality), has a free cause.

c) Even if we can detect natural laws in actuality and hence some kind of 'necessity', this does not refute the above, for if we were to follow events back to the beginning of the causal chain, we could discover freely acting causes alone.

For Climacus, as we have seen, there are only two possible ways of 'being': either as the 'ideal' and therefore as necessary or as the factual in which there resides no necessity. The crucial inference which Climacus now makes on the basis of this already established dichotomy is that a complete lack of 
necessity indicates freedom. So, although Climacus does not here provide us an elaborate definition of either necessity or freedom, he does indicate the relation that exists between them - one of mutual exclusion: either freedom is posited or necessity, but never both. Therefore, it becomes evident that Climacus directly opposes any kind of mediation between necessity and freedom.

Kierkegaard (through Climacus) is so absolute about the incompatibility of necessity and freedom within history that for him even the so-called necessary laws of nature do not demonstrate the presence of necessity in actuality. What is Climacus' reasoning for this contention? It runs as follows: when we discover causes (natural laws) that seem to necessarily produce certain effects, regression down the causal chain to the first cause will always return us to a freely acting cause. Thus Climacus writes:

The intervening causes are misleading in that the coming into existence appears to be necessary; the truth about them is that they, as having themselves come into existence, definitively point back to a freely acting cause. As soon as coming into existence is definitively reflected upon, even an inference from natural law is not evidence of the necessity of any coming into existence. $(P F, 75)$

Climacus' argument can be reconstructed as follows:

a) Any 'coming into existence' has to undergo a change.

b) Necessity prohibits any kind of change.

c) Thus, no 'fact' can occur necessarily.

d) When we come across certain natural laws that imply that certain facts occur in a necessary way, returning to the first cause in the causal chain will always demonstrate the occurrence of this 'coming into existence'.

e) Thus, even strict causal chains necessarily have a free beginning.

The nature of necessity is still to be determined. It might be argued on this basis that causal necessity can coexist with history and with historical contingency. If, however, this is the case, it is difficult to conceive Kierkegaard's absolute separation of them. The answer, I argue, is simple: Kierkegaard's specific conception of 'necessity' here is a form of logical necessity. This is apparent because of Climacus' acceptance of the existence of natural laws and the existence of causal necessity. I would contend, therefore, that his argument proceeds as follows: whenever we wish to fully know historical existence by means of causal necessity, this involves the application of logical analysis. This logical analysis, however, is incompatible with the very nature of historical existence. I return to this issue at length in what follows.

Climacus thus, creates an insurmountable hiatus between 'necessary' and 'existing' being. For Climacus freedom can only be where necessity can- 
not be. A radical dualism is in play. Although Climacus has yet to define these concepts, their meaning does become determinate by means of their mutual opposition.

Roberts interprets Climacus' argument in the following way:

Even if we can explain the actualization of possibility $a$ by reference to the actualizations of other possibilities (which are the causal antecedents for $a$ ) still this string of possibilities is only one among an indefinitely large set of strings. (1986: 106)

Roberts thus emphasises the contingency of the first cause in any causal chain as the crucial argument Kierkegaard uses to demonstrate the lack of necessity within historical existence.

Kierkegaard indeed makes this point but only to underline the contrast between absolute causality and historical existence. As we shall see, by 'historical existence' he means specifically human historical existence. Roberts' point is useful for the examination of causality in nature but not enough to successfully reconstruct Kierkegaard's analysis of 'historical existence'.

\section{The Historical}

As we have already established, one primary characteristic of history is that it 'has come into existence' and thus we have to attribute to it freedom and lack of necessity. Another primary characteristic is that history refers only to human history and not to nature's history. Nature does exist, but has no memory of its existence; and although nature has a past, a present and a future, nature cannot be 'free' because nature cannot be aware of its past in a way that could enable it to decide about its present and its future. It is in this vein that Climacus speaks of a 'redoubling' of human being's 'coming into existence':

Yet coming into existence can contain within itself a redoubling, that is, a possibility of a coming into existence within its own coming into existence. Here, in the stricter sense, is the historical, which is dialectical with respect to time. $(P F, 76)$

I am arguing that Kierkegaard is here clear that 'history' refers solely to human history. Only human beings have the capacity to relate themselves to their past in a way that makes them capable of freely choosing their future. ${ }^{5}$

Mackey nicely sums up this direct connection between freedom and history:

\footnotetext{
${ }^{5}$ In The Sickness Unto Death, Kierkegaard expresses the idea that the self is a relation that relates itself to itself. Nature does not have this relation, and consequently it does not have the 'redoubling' that constitutes historical (human) existence.
} 
The eternal, which is also the necessary, has no history in any sense. It sustains no relationship to possibility, actuality, change, or freedom. Nature is pure synchrony (spatiality), save for the fact that it has, as a whole, come into being. History is pure diachrony (temporality), save for the fact that it presupposes space as its locus...Strictly speaking, nothing happens in nature. It is always, if cyclically, the same, for which reason there are laws of nature. But historical events, for which there are no laws, are the operations of freely working causes terminating in the working of an absolute free cause. (1986: 127)

While I agree with Mackey's stress on the absence of necessary laws in historical events, it strikes me that Mackey fails to take his conclusion far enough, so as to draw out the philosophical implications of Kierkegaard's approach to history. As I have already argued, what previous commentators of the Interlude have failed to discern is that Kierkegaard is attempting to answer both the ontological question and the epistemological question about history therein.

In order to defend properly my above mentioned claim I will schematise the way in which Climacus answers both of these questions. In regard to the ontological question about the nature of history Climacus argues: a) history is always human history and b) freedom reigns within it, (the kind of freedom that excludes any kind of necessity). In terms of the epistemological question, there is still much to determine; however, preliminarily one can conclude that the knowledge we have of nature by means of natural laws is unavailable for historical cognition.

However, before proceeding further with the epistemological question, we need to emphasise once more the fact that Climacus states that history, human beings and freedom constitute a fully unified nexus. Furthermore, this implies that such a direct connection between the 'historical' and 'freedom' leaves human beings as the sole historical agents. Human beings alone make history through their own free choices. Past and present are human actualities while human future is human possibility. And so to redefine the present in the light of the past and the future is the distinguishing mark of a properly human freedom.

Howland makes a similar point in regard to Climacus' argument in the Interlude: ' $[\mathrm{O}]$ nly human beings are self-consciously historical, continually redefining themselves in terms of their actual pasts and possible futures. And this "dialectical" process of redefinition, or of mediating the present in the light of actual pasts and possible futures, is a sign of human freedom' (2006: 161).

However, missing from Howland's account are the following elements: a) human freedom is mainly oriented towards future decisions and b) human freedom is a matter of human will (and so of human ability to make decisions). What is more, what Howland fails to see, is that this freedom is always 
accompanied by an acceptance (from the side of the people who freely make these decisions) of human responsibility.

\section{The Past}

It has been already argued that for Kierkegaard necessity cannot be found within history. In what follows, I will give further details on how Kierkegaard defends the absolute lack of necessity in history. To be more specific, I will analyse how Climacus argues against the notion that the past can be necessary. By doing so, I intend to further exhibit Kierkegaard's rejection of necessity in history.

Usually, when we think of history we think of the past. In fact, the customary and perhaps most trivial definition of history is the 'past' of something, or something that happened in the past. Yet, as we have seen, for Climacus, although nature has a past, it cannot really have a history. Only human beings have history, because only human beings can understand what it means to have a past, a present and a future. Moreover, Climacus argues at the same time that necessity cannot be found within history. One possible objection to this latter point runs as follows: the past is necessary because the past cannot be changed:

What has happened has happened and cannot be undone; thus it cannot be changed. Is this unchangeableness the unchangeableness of necessity?... What has happened has happened the way it happened; thus it is unchangeable. But is this unchangeableness the unchangeableness of necessity? $(P F, 76-77)$

Climacus' response is, once more, simple: every past, before becoming a past was a present; this present became present through 'coming into existence'. And, as we know, the present comes into existence freely. Although we cannot undo or change the past, we can think of this past as different: it could have been other than it is, i.e. the past is contingent.

Here we have one more indication of the nature of Kierkegaardian necessity: it is logical necessity. Contingency allows room for causal necessity (under specific conditions). As previously noted, this logical necessity has certain philosophical implications regarding the ability to fully know historical facts. We cannot expect ourselves to be able to fully know and understand history by applying logical analysis to historical facts. The existence of causal necessity applies merely to nature and not to human history. Moreover, logical analysis is totally incompatible with (human) historical existence. In this way Kierkegaard does not depend on contingency to exclude necessity. Kierkegaard renders history a field of actualisation, instead of a field of cognition. 
For example, we cannot change how World War II ended; this, however, does not mean that this past could not have developed in the opposite direction. Mercer is thus right to underline that:

The past is the result of the choice or choices made among the possibilities of the future in the present and those possibilities are different and varied. It does not follow that one particular choice result in a particular past... If the past and the future are necessary then they are neither past nor future, but simply are. (2000: 127-128)

The concept of history involves continuous change, and consequently involves freedom to so change. Mercer's analysis, however, still fails to acknowledge that Kierkegaard's analysis is not focused on the effort to understand how past history 'results' in present and future history. On the contrary, Kierkegaard argues in favour of the actual existence (and thus historical existence) of (human) freedom of will and (human) freedom of choice.

As Climacus spells out, there exists a continuous interaction between our past, present and future. We understand ourselves and our reality through the continuous effort to choose between different possible choices. Hence, Climacus points out that, if it is asserted that we lack the freedom to make choices, so that we are simply subjected to necessity, then we end up living in a permanent present, instead of willing history. In fact, as we have seen, Kierkegaard has already made clear that 'necessity always relates itself to itself at the same way' $(P F, 74)$. It follows therefore that, necessity is eternally and so cannot become 'history'. What is absolutely crucial here is that Kierkegaard focuses on the capacity of human beings to will and so choose to make history, rather than focusing on the ability of human beings to know history.

Furthermore, Climacus goes on to provide another reason to avoid attributing necessity to the past. He claims that if we consider the past necessary, we must attribute such necessity to the future as well, because:

If the past had become necessary, the opposite conclusion could not be drawn with respect to the future, but on the contrary it would follow that the future would also be necessary. If necessity could supervene at one single point, then we could no longer speak of the past and the future. To want to predict the future (prophecy) and to want to understand the necessity of the past are altogether identical, and only the prevailing fashion makes the one seem more plausible than the other to a particular generation. $(P F, 77)$

In order to understand Climacus' argument here, one needs to keep in mind that for him 'necessity is and it always is in the same way'. If we accept that the past is necessary, then, one must also accept that the future, which has already been transformed into the past, was also necessary. That is, each past moment is previously a present moment and, before that, a future moment. 
By arguing the above, Climacus intends to indicate that, if we accept that our past is necessary, then the future and the present of that past must also be necessary. Such is the reason behind his claim that 'prophecy' and understanding the past as necessary 'are altogether identical'. We can predict the future only if it occurs in a necessary way (i.e. according to necessary laws). Moreover, and this is the crucial point, Climacus employs the same line of reasoning on the past: we cannot understand the past as necessary, for the past is merely one out of many equally possible pasts that could occur.

Therefore, we are now able to take a step back to reflect on Climacus' argument so far. This argument, we have seen, constitutes an answer to the ontological question of history: the nature of history is to be conceived exclusively as the history of human beings and so must be directly connected with 'freedom'. Provisional conclusions are also possible concerning the epistemological question of history: one cannot apply 'scientific' methods to history in order to know it in the same way as one applies them in the field of nature. We cannot aspire to find necessary laws in history.

This is also the reason why Climacus goes on to argue that knowledge of the past does not confer necessity upon it:

The past is not necessary, inasmuch as it came into existence; it did not become necessary by coming into existence (a contradiction), and it becomes even less necessary through any apprehension of it... If the past were to become necessary through the apprehension [of it], then the past would gain what the apprehension lost, since it would apprehend something else, which is poor apprehension. If what is apprehended is changed in the apprehension, then the apprehension is changed into a misunderstanding... [K] knowledge of the past does not confer necessity upon it-for all apprehension, like all knowing, has nothing from which to give. (PF, 79-80)

Climacus' argument can be reconstructed as follows:

a) While the past certainly existed, it is not necessary.

b) Our apprehension of the past cannot make it necessary. ${ }^{6}$

c) If, through apprehension, one could make it necessary, then either one would apprehend the past in the wrong way, (because the past is not necessary), or such apprehension would have the power to change the essence of the past, which - for Climacus - is absurd. ${ }^{7}$

Hence, Climacus here turns far more explicitly to the epistemological question of history and so the question of the knowledge we are able to have of history: no logical necessity is either discernible in history or can be attrib-

\footnotetext{
${ }^{6}$ Kant obviously disagrees with this philosophical claim. Such a disagreement cannot, however, be further pursued in this analysis.

${ }^{7}$ Again, this is not absurd for a transcendental idealist.
} 
uted to it by means of cognition. While one can be sure, for example, about simple facts (the defeat of Germany in the Second World War, for example), one cannot fully apprehend how exactly it happened that this outcome occurred rather than any other.

Such an example demonstrates why for Climacus it is so important to directly connect the ontological issue of the nature of history to the epistemological issue of the knowledge of history. Freedom (which is defined as lack of necessity), on the one hand, characterises the nature of history, but, on the other hand, excludes any scientifically accurate historical knowledge. Causal necessity applies only to nature, so human history cannot be totally analysed by means of causal thinking.

That is, what emerges in the Interlude is a demand to approach the whole field of philosophy of history from another perspective. A demand emerges to treat history differently. Such an alternative conception of history would ensure that historical knowledge remains open to doubt and alternative forms of apprehension. And such an alternative conception of history is only made possible for Climacus by means of the central contention that 'history' is par excellence the field of freedom and so a realm in which human beings cannot be totally secure about their knowledge. When Climacus excludes necessity from history, this brings about a complete paradigm shift in the philosophy of history, starting with the ineluctable 'uncertainty' of our historical knowledge.

Moreover, the significance of such a shift is precisely what I have argued is neglected by all the above mentioned commentators. That is, they fail to take seriously the fact that for Climacus the problem of 'freedom' applies equally on an ontological and epistemological level historically. At the very moment that Climacus removes any necessity from history, he generates uncertainty in historical cognition. As scholars, we therefore cannot analyse his argument in the Interlude from either merely the ontological level of the nature of history or merely from the epistemological level of historical knowledge. To do so would radically distort Climacus' newly-won perspective.

\section{The context to the Interlude}

The conclusions Climacus reaches in the Interlude need to be placed in a broader context, for their purpose can only become fully clear if we consider their role in $P F$ as a whole. The question that orients $P F$ is the extent to which one is able to come theoretically to terms with the Incarnation of Jesus Christ. Climacus answers this question first by considering logical and scientific methods as a possible means of understanding the Incarnation, but, unsurprisingly, in the course of his argument, this approach is rejected wholesale. The Interlude in particular contributes two significant claims 
to this overall argument: a) historical facts, like the Incarnation, cannot be known beyond any possible doubt and b) doubt is not overruled by further knowledge but by an act of will.

We have already thoroughly examined Climacus' argument concerning historical facts and the nature of their knowledge. Before I proceed on analysing the way Climacus approaches doubt, it would be beneficial to my analysis to offer the general context of the Interlude.

The reason, that makes me to refer to the context of the Interlude after the Interlude and not before it, is that 'context' here can be defined as a further conceptual justification of the statements we examined in the Interlude. That is, we need first to know what is argued in the Interlude, because we, in a way, need to start with the 'facts'. Here, as 'facts' we take the Kierkegaardian statements concerning history and the historical.

This section also is a useful introduction to the way Climacus argues about doubt, belief and freedom in the last section of the Interlude. It is so, because the problem of the exact nature of belief and doubt concerned Climacus through his three texts $J C, P F$ and $C U P$ and not only in the Interlude. Hence, examining the way Climacus approaches the problem of belief and doubt in JC, PF and CUP can help us understand better his argument in the Interlude. Climacus' general view of the nature of freedom in these three texts can introduce us to the way he approaches freedom in the last part of the Interlude. It will become easier for us to fully grasp his final approach to freedom if we, first, examine the way freedom is approached through the whole oeuvre of Climacus.

Climacus' argument in the Interlude over the nature of history and the nature of our historical knowledge is part of a more general attack aimed at those who argue that we can overcome our doubts about the Incarnation through historical knowledge or through scientific methods. ${ }^{8}$ It is in this vein that in CUP Climacus returns to a passage from PF:

As is well known, Christianity is the only historical phenomenon that despite the historical-indeed, precisely by means of the historical-has wanted to be the single individual's point of departure for this eternal consciousness, has wanted to interest him otherwise than merely historically, has wanted to base his happiness on his relation to something historical. $(C U P, 15)$

The problem with a philosophical approach to the Incarnation is central to Kierkegaard's thought even prior to PF and CUP: '[C]hristianity's claim that it had come into the world by a beginning that was simultaneously historical and eternal had caused philosophy much difficulty' (JC, 134-135).

\footnotetext{
${ }^{8}$ For a thorough examination of the disputes in Denmark in Kierkegaard's time about the correct philosophical interpretations of the Incarnation, see Stewart (2003: 336-377).
} 
In each of these three texts, the same pseudonym, Climacus, is employed, and this suggests to me that it is through this pseudonym of Climacus that Kierkegaard most fully explicates his position concerning the knowability of the Incarnation.

Hence, the arguments in the Interlude to a large extent rest on and contribute to this broader context of Climacus' writings as a whole.

At the heart of Climacus' analysis in each of these three texts lies the problem 'of the confusion of historical and eternal categories' (i.e. freedom and necessity), the problem of the definition of actuality and the definition of doubt. We have already followed the fate of the first two problems in the Interlude. Before I turn to the third one it would be beneficiary for my analysis to consider their role more generally in Climacus' oeuvre.?

In $J C$, for example, the problem of necessity is articulated as follows:

Philosophy, however, wanted to do something even more difficult: it wanted to permeate everything with the thought of eternity and necessity, wanted to do this in the present moment, which would mean slaying the present with the thought of eternity and yet preserving its fresh life. (JC, 142-143)

Having stated the problem thus, Climacus continues to explore the possibility of a relation between necessity and actuality. This is a question to which he will answer negatively in the Interlude. Indeed, in CUP Climacus underscores this position:

Placing necessity together with the interpretation of world history, as has been done by modern speculative thought, has only caused great confusion, whereby possibility, actuality, and necessity are confused. (CUP, 343)

The nature of doubt and belief and their role regarding the problem of the historical knowledge finds, for Climacus, its final solution in the last section of the Interlude. In the second part of $J C$, however, Climacus gives us his first attempt to define them. One of the ways it is possible to discern that Climacus' definitive answer is in the Interlude is that Kierkegaard makes a very similar point (to the one he makes in the Interlude) in his Journals:

It is claimed that arguments against Christianity arise out of doubt. This is a total misunderstanding. The arguments against Christianity arise out of insubordination, reluctance to obey, mutiny against all authority. Therefore, until now the battle against objections has been shadowboxing, because it has been

${ }^{9}$ I cannot argue that the existence of the same pseudonym (Climacus) as the author in $J C, P F$ and CUP proves their intellectual and conceptual proximity. I will not claim that the texts mentioned above are totally and directly connected to each other. These three books however constitute the necessary general context for the complete understanding of the Interlude. For the problem of Kierkegaard's pseudonimity see the introduction of Giles (2000: 3-10). 
intellectual combat with doubt instead of being ethical combat against mutiny. (Kierkegaard 1970: Vol. I, 778 (Pap. VIII A 7))

Apparent in both PF and the Journals is Kierkegaard's insistence that knowledge is not appropriate means to battle against doubt. On this issue, Climacus represents Kierkegaard's view. The broader context makes this even more apparent. Already in $J C$ one can detect a shift from an epistemological view of our existence to an ethical one. Faith, rather than knowledge, is able to counter doubt. Such a development continues throughout PF and CUP. In the latter text Climacus points out that ethical knowledge is prior to any other knowledge. ${ }^{10}$ To acquire ethical knowledge however, means to be able to decide about our lives. It is a matter of will. Kierkegaard, or Climacus, always defines actuality in terms of making decisions and thus, for him: 'The individual's own ethical actuality is the only actuality' (CUP, 327).

Unsurprisingly given these points of convergence, all three texts are in agreement on the nature of historical cognition. As we have seen in the Interlude, knowledge of the historical cannot aspire to being 'absolute' or complete; there will always be a 'gap' in our knowledge constituted by the very moment of 'coming into existence'. Objective scientific laws have no application in the field of history. Similar views are promulgated in CUP and $J C$, as we shall now see.

Indeed, it is in $J C$ that Climacus first notices the 'inappropriate' confusion of necessity and history which will be so important for the argument of the Interlude:

... [I]t seemed strange to him that people talked so imprecisely, that they confused historical and eternal categories in such a way that when they seemed to be saying something historical they were saying something eternal. (JC, 134)

Historical knowledge is but a relative knowledge and as such cannot act as a remedy to our doubts. In $J C$, Climacus specifically refers to the problem of 'objective thinking' in relation to the problem of doubt in general: 'Thus it would be a misunderstanding for someone to think that doubt can be overcome by so-called objective thinking' $(J C, 170)$. Without delving into the problem of what exactly Kierkegaard means by the term 'objective thinking' in any detail, it is surely correct to note that it includes some reference to objective scientific methods. ${ }^{11}$ In the Interlude, as we have seen, Climacus will argue that such 'objective thinking' is not applicable in the field of history.

\footnotetext{
${ }^{10}$ See for example Kierkegaard, CUP, 317, where Climacus refers to Socrates.

${ }^{11}$ In CUP Climacus refers to 'objective thinking' in terms of a thinking that can be acquired through objective means and so is more 'credible' than 'subjective thinking'. Of course Climacus' arguments in CUP are ultimately intended to invert this relation: it is subjective thinking that it is more 'reliable' than objective thinking. What it is important here for my analysis is to underline the fact that objective thinking includes scientific methods.
} 
Climacus' argument concerning the lack of necessity in history and the freedom that pertains in actuality is not restricted only at the Interlude. Instead, it is explored also in $J C$ and CUP. Climacus in the last section of the Interlude will further define the exact nature of the relations between knowledge, belief, doubt and freedom in history. What we should know however, about the context of this last section, is that Climacus underlines the contingency of the historical. Such contingency refers both to the nature of history and it signifies the lack of necessary laws pertaining to freedom in the field of history and hence to the impossibility of complete historical knowledge.

... [T]here lies here the entire misunderstanding that recurs time and again in modern philosophy: to make the eternal historical as a matter of course and to assume an ability to comprehend the necessity of the historical. Everything that becomes historical is contingent... (CUP, 98)

In the last section of the Interlude Climacus, as we are about to see, argues that doubt is not the result of 'less' knowledge but, instead, it is a matter of will. Climacus will argue that the existence of freedom in history results at the lack of 'absolute' historical cognition. He will continue arguing that doubt and belief are responses to this freedom. That is, because we are free (in history), we can either choose to doubt or to believe (in history and the historical). Freedom and doubt and belief are absolutely interconnected.

\section{Doubt, belief, will and freedom in history}

Climacus has already argued that freedom and not necessity exists within history. From this ontological claim he has also argued that we cannot know history in an absolute manner. Climacus now will conclude his argument concerning both his ontological claim and his epistemological one by defining the exact nature of belief and doubt. He will argue against those who claim that doubt results from lack of knowledge and thus 'more' knowledge can 'nullify' doubt. ${ }^{12}$

Climacus will relate freedom in history with freedom of will and freedom of choice. He will explain doubt and belief as direct products of these two freedoms and in this way he will conclude his argument in the Interlude.

${ }^{12}$ The eighteenth century was the 'age of enlightenment', the age of reason. People believed in the power of reason to clear up any mystery. A further development of this intellectual attitude was the 'Jesus of history' debate. People like Friedrich Schleiermacher and David Friedrich Strauss argued against the historical accuracy of the Gospels and tried to use reason in their effort to explain Bible. Kierkegaard found himself living within this historical/intellectual context and he definitely argued against the importance of reason for faith because he believed that he had to defend faith from logic and reason. This is why Kierkegaard tries so hard in the 'Interlude' to separate belief and reason arguing that belief and faith are products of will and not of reason. 
Climacus states twice that 'immediate sensation and immediate cognition cannot deceive.' The problem comes with 'reflection' ( $P F, 81-82)$. Those who think that they can overcome doubt through certain and secure historical knowledge are mistaken. We have already seen that Climacus argues that there is no secure historical knowledge. Now he goes on to state that, if we wish to overcome the kind of doubt that comes with reflection, we have to do so by means of our will instead of cognition.

That is, Climacus here claims that belief and doubt are acts of freedom, expressions of the will, rather than products of cognition and theoretical understanding: '.. belief is not knowledge but an act of freedom, an expression of will' (PF, 82-83). Thus, for Climacus, 'The conclusion of belief is no conclusion but a resolution'. The term 'conclusion' here refers to a logical process, whereas 'resolution' consists in an act of will. Hence, Climacus argues that belief and doubt are not modes of knowledge, but opposing passions. ${ }^{13}$ We are free either to doubt or to believe. We are free to remain skeptical in the face of the possible interpretation of the historical facts or we can will to believe them. Precisely because every 'coming into existence' occurs freely, one can never be fully certain about it: historical cognition can never be certain. This is why Climacus adds: 'Belief is a sense for coming into existence...' (PF, 84)

It might be argued that there are historical facts known to us without any kind of act of will. When a car, for example, crashes into another car, this is an indisputable fact; we cannot choose either to believe it or to doubt it. Climacus though, does not consider this mere fact of the crash as 'historical'. Instead, for Climacus, a historical fact includes the 'interpretation' of this fact as well. Questions such as 'Whose fault is this accident? Is it really a car accident or it is a 'fake' one for the shooting of a movie?' are inextricably involved here.

Kierkegaard has already asserted, as we have seen, that only human beings can have history, because only human beings can be aware of the active connection between their past, their present and their future. Immediate sensation of the bare fact does not constitute a historical fact for Kierkegaard. Historical agents need to mediate these mere occurrences through interpretation. Another objection is possible here, however: it might be argued that scientific facts of nature also need interpretation, so why can't one consider these as historical facts? Kierkegaard's answer is that belief and doubt are not modes of knowledge. Scientific facts need interpretation but such interpretation is epistemological. On the other hand, the interpretation of historical

${ }^{13}$ Kierkegaard, $P F, 84$. 'Passion' here does not signify emotion or sensual desire. It refers instead to an act of will. 
facts takes place through the will; it is therefore an existential characteristic of our historical existence.

The raw immediacy of what happens does not constitute the historical fact. Interpretation is needed and yet, Climacus emphasises, such interpretation will never bring about the kind of knowledge involved in cognition of nature. What is more, precisely because history is always the history of human beings for Climacus, reflection on the intention, motivation and willing involved in history is absolutely necessary. This is the reason why for Climacus the ontological question cannot be separated from the epistemological one. $^{14}$

It follows that history requires the active participation of human beings, choosing actions, intending actions and willing actions. It is this activity $\mathrm{Ki}-$ erkegaard designates with the term 'passion'.

In order to pinpoint this active participation in a more precise manner, it is worth turning to Roberts' analysis of the epistemology implicit in the Interlude. Roberts reconstructs Climacus' concepts of belief and doubt as follows:

No historical personage (or indeed any event at all) is a flat, straightforward, self-interpreting brute datum given to an unambiguous apprehension. Every historical judgment, whether made by an eyewitness of the personage in question or by someone in a subsequent generation dependent on testimony, is shaped ultimately by a set of beliefs held by the individual making the judgment, which beliefs form a kind of interpretive mold out of which the judgment emerges, and in virtue of which the judgment is certified. (1986: 126-127)

While there is much to be applauded in this passage, what I dispute in Roberts' interpretation of the Interlude is his contention that it is such epistemological issues alone that are at stake. For Roberts, the epistemology laid out above is 'the central insight of Climacus' Interlude' (126).

I am claiming that these epistemological issues presuppose initial conclusions concerning the ontological nature of history. It is, to repeat, only by approaching Climacus' arguments in the Interlude through both questions that its meaning, purpose and function becomes completely clear.

${ }^{14}$ Mercer points out that 'freedom and faith become the elements that are the most central to the historical.' He further argues that "the matter of history is not a metaphysical question but an existential question." Mercer (2000: 138-141). What he is not doing, however, is to show us how these two Kierkegaardian claims about history and the historical are interconnected. 


\section{Epilogue}

If we consider history to be known through the application of general and necessary laws, (the way nature can be known), our job as philosophers would be much easier. Historical existence would be more certain and secure. If, on the other hand, we subscribe to Climacus' concept of history, then everything suddenly becomes insecure and 'scientific' accuracy is unavailable to us. Yet, we must still attempt on this view to become responsible for the making of our history. Of course, this might seem an impossible task; personally each one of us may feel too 'small' to try to influence history or to try to understand it. But then again, this too fulfills Climacus' promise: 'to make difficulties everywhere' (CUP, 187).

Kierkegaard's approach to the problem of history and, consequently, his philosophical conclusions are original and do deserve our scholarly attention. What makes the Kierkegaardian approach to history original is its focus on the importance of the future as the main 'temporal' dimension of history.

While other philosophers have also pointed out the contingency of history, (Duns Scotus for example), and while Saint Augustine gave us an analysis of free will similar to the Kierkegaardian one, Kierkegaard redirects the historical focus from the past to the future. The main historical tendency is completely redirected from the trivial tendency we usually recognize in history.

We can fully capture the dynamic of the Kierkegaardian approach only if we realize that history under his approach becomes the human existential need to create a future history and not the scientific need to understand a past history. More than that, with Kierkegaard's approach, history suddenly acquires a solid ethical dimension.

Ethical human responsibility in history is the most important implication of Kierkegaard's concept of history. If we choose to follow his argumentation, than we cannot any longer view history as an indifferent and neutral field within which all that matters is 'historical facts'.

The Kierkegaardian argumentation offers us, besides an interesting existential approach to history, a critical and most needed historical element, i.e. an ethical criterion to choose what kind of (future) history we need to have. We need only to remember what kind of 'evils' we, human beings, battled during the $20^{\text {th }}$ century to understand the importance of the Kierkegaardian approach to history. Because, if we choose to listen to Kierkegaard, history has nothing to do with knowing the historical data regarding this battle and history becomes our ethical commitment to create our future history in such a way that this 'evil' will not happen again. 


\section{Bibliography}

Fenves, Peter. 1993. 'Chatter': Language and History in Kierkegaard (Stanford, California: Stanford University Press).

Gonzalez, Dario. 2007. “Trendelenburg: An Ally against Speculation”, in Jon Stewart (ed.), Kierkegaard Research: Sources, Reception and Resources, Vol. 6, Tome I, Kierkegaard and his German Contemporaries (Aldershot: Ashgate, 2007), 309-335.

Green, Ronald M. 1992. Kierkegaard and Kant, The Hidden Debt (Albany: State University of New York Press).

Howland, Jacob. 2006. Kierkegaard and Socrates (Cambridge: Cambridge University Press).

Giles, James (ed.). 2000. Kierkegaard and Freedom (New York: Palgrave).

Kierkegaard, Soren. 1970. Soren Kierkegaard's Journals and Papers, ed. and trans. by Howard V. Hong and Edna H. Hong, assisted by Gregor Malantschuk, vol. 1 (Bloomington and London: Indiana University Press).

The Sickness unto Death, KW XIX, trans. by Howard V. Hong and Edna H. Hong (Princeton, New Jersey: Princeton University Press).

—. 1987. Philosophical Fragments, KW VII, Johannes Climacus, or De omnibus dubitandum est, KW VII, trans. by Howard and Edna H. Hong (Princeton: Princeton University Press).

1992. Concluding Unscientific Postscript, KW XII, 1, trans. by Howard and Edna H. Hong (Princeton: Princeton University Press).

Mackey, Louis. 1986. Points of View: Readings of Kierkegaard (Tallahassee: Florida State University Press).

Mercer, David Emery. 2000. Kierkegaard's Living-Room: The Relation between Faith and History in Philosophical Fragments (Montreal: McGill-Queen's University Press).

Roberts, Robert C. 1986. Faith, Reason and History: Rethinking Kierkegaard's Philosophical Fragments (Macon Ga: Mercer University Press).

Stewart, Jon. 2003. Kierkegaard's Relations to Hegel Reconsidered (Cambridge: Cambridge University Press).

Thulstrup, Niels. 1980. Kierkegaard's Relation to Hegel, trans. by George L. Stengren (Princeton, New Jersey: Princeton University Press). 